\title{
AFLATOXIN M IN MILK BY IMMUNOAFFINITY COLUMN CLEANUP WITH TLC/HPLC DETERMINATION
}

\author{
Luzia Shundo*; Myrna Sabino
}

Instituto Adolfo Lutz, Seção de Química Biológica, São Paulo, SP, Brasil

Submitted: August 17, 2005; Returned to authors for corrections: January 09, 2006; Approved: March 15, 2006

\begin{abstract}
During 2002 and 2003, a total of 107 samples of raw, pasteurized and ultrahigh treated temperature (UHT) milk commercialized in the cities of São Paulo and Marília (SP) were analyzed for the presence of aflatoxin $\mathrm{M}_{1}$ $\left(\mathrm{AFM}_{1}\right) . \mathrm{AFM}_{1}$ was detected in $79(73.8 \%)$ of milk samples, ranging from $<0.02$ to $0.26 \mu \mathrm{g} / \mathrm{L}$. The samples were analyzed using an immunoaffinity column for cleanup and a thin layer chromatography for determining $\mathrm{AFM}_{1}$. The parameters, such as recovery, repeatibility, detection and quantification limit were evaluated to optimize this method (in-house). Based on spiked samples, the recovery values ranged from 85.83 to $73.86 \%$ at levels of $0.010-0.50 \mu \mathrm{g} / \mathrm{L}$, respectively, and the relative standard deviation for repeatibility ranged from 7.73 to $2.08 \%$. The quantification limit was $0.02 \mu \mathrm{g} / \mathrm{L}$. The results of some samples analyzed by this method demonstrated a satisfatory correlation when compared with High Performance Liquid Chromatography (HPLC). In conclusion, immunoaffinity column cleanup gave excellent results for recovery, sensibility and sample through put. Despite the high rate of occurrence of $\mathrm{AFM}_{1}$ in samples in both cities, the contamination level could not be considered a serious public health hazard, according to Brazilian legislation.
\end{abstract}

Key words: milk, aflatoxin $\mathrm{M}_{1}$, thin layer chromatography, immunoaffinity column

\section{INTRODUCTION}

In October 2002, the Brazilian Ministry of Health (1) established the maximum acceptable limit of aflatoxin $M_{1}\left(A F M_{1}\right)$ in $0.5 \mu \mathrm{g} / \mathrm{L}$ for fluid milk and $5 \mu \mathrm{g} / \mathrm{L}$ for powder milk following the MERCOSUL Technical Regulations (12). Two groups of countries have adopted different regulatory limits: $0.05 \mu \mathrm{g} / \mathrm{L}$ and $0.5 \mu \mathrm{g} / \mathrm{L}$ respectively. The European Commission by the Regulation CE 1525/98 and Directive 199/29/CE has implemented a limit of $0.05 \mu \mathrm{g} / \mathrm{L}$ of $\mathrm{AFM}_{1}$ in liquid milk, whereas the Food and Drug Administration (FDA) has established an action level of $0.5 \mu \mathrm{g} / \mathrm{L}$ in whole, low fat and skim milk.

Although $\mathrm{AFM}_{1}$, the hydroxylated metabolite of Aflatoxin $\mathrm{B}_{1}\left(\mathrm{AFB}_{1}\right)$ is less carcinogenic and mutagenic than $\mathrm{AFB}_{1}$, it exhibits a high level of genotoxic activity and certainly represents a health risk because of its possible accumulation and linkage to DNA. Monitoring of $\mathrm{AFM}_{1}$ levels in animal studies has shown that the rate between the amount of $\mathrm{AFB}_{1}$ ingested by cows and the quantity excreted in milk is usually 0.2 to $4 \%$ (8). Milk has the greatest demonstrated potencial for introducing $\mathrm{AFM}_{1}$ into the human diet and the possible presence of $\mathrm{AFM}_{1}$ in milk and their products represents a worldwide concern mainly because these products are widely consumed by children, the major consumers, who are more susceptible to the adverse effects of micotoxins.

The incidence of $\mathrm{AFM}_{1}$ contamination is often higher in commercial milk than in raw farm milk because of uncontaminated bulk milk is often diluted with contaminated samples. However, as result of this dilution, high $\mathrm{AFM}_{1}$ contamination levels in commercial milk seldom occur (15). Efficient control of $\mathrm{AFM}_{1}$ in milk requires efficient and easily performed analytical methods, allowing low quantification which increases the percentage of positive samples.

In Brazil, there is little data in the literature on the occurrence of $\mathrm{AFM}_{1}$ in raw and commercialized milk. The purpose of this work was to investigate of $\mathrm{AFM}_{1}$ in raw, pasteurized and UHT

*Corresponding Author. Mailing address: Instituto Adolfo Lutz, Seção de Química Biológica, Av. Dr. Arnaldo, 355, Vila Clementino. 01246-902, São Paulo, SP, Brasil. Tel.: (+5511) 3068-2922, Fax: (+5511) 3062-5363. E-mail: lushundo@ial.sp.gov.br 
milk commercialized in the cities of São Paulo and Marília (SP), Brazil, in 2002/2003. The samples were analyzed by thin layer chromatography (TLC), immunoaffinity column (IC) and some samples were also submitted to HPLC for results comparison.

\section{MATERIALS AND METHODS}

\section{Samples}

A total of 107 samples of milk were analyzed to determine $\mathrm{AFM}_{1}$. Twenty-two samples of raw milk from grazing cows supplemented with animal feed were collected from farms across the region of Marília (SP), Brazil, in 2002 and 2003. In the same period, 42 samples of UHT milk and 43 samples of pasteurized milk were collected from supermarkets in the cities of São Paulo and Marília (SP). Both the raw and pasteurized milk were kept on the ice during the transportation and raw milk samples were analyzed immediately upon arrival at the laboratory. The pasteurized milk samples were stored at $5^{\circ} \mathrm{C}$ and analyzed before expiration.

\section{Determination of $\mathrm{AFM}_{1}$}

Milk samples were analized for the presence of $\mathrm{AFM}_{1}$ using an immunoaffinity column for clean up and HPLC with fluorescence detection for determination based on the method of Grosso et al. (7) and Shundo et al. (21). The milk samples $(100 \mathrm{~mL})$ were centrifuged at $2000 \mathrm{xg}$ for 15 minutes and the upper fat layer was discarded. The skimmed milk was passed through an immunoaffinity column (AFLAPREP M, R-Biopharm Rhône Ltd). The column was washed with water $(40 \mathrm{~mL})$ to remove extraneous non-specific material. Following, the AFM bound to the antibody was released by the elution with $2.5 \mathrm{~mL}$ acetonitrile-methanol $(3: 2 ; \mathrm{v} / \mathrm{v})$ and $2.5 \mathrm{~mL}$ methanol. The eluate was evaporated to dryness using a stream of $\mathrm{N}_{2}$.

The TLC procedure was developed, dissolving the $\mathrm{AFM}_{1}$ residue in $150 \mu \mathrm{L}$ of toluene-acetonitrile $(9: 1 ; \mathrm{v} / \mathrm{v})$. On the TLC plate (TLC aluminum sheets, $20 \times 20 \mathrm{~cm}$, Silica gel 60 ), $50 \mu \mathrm{L}$ of sample and spots of working standard were applied. The plate was developed in chloroform-acetone-isopropanol (87:10:3; $/ \mathrm{v})$. After the plate had dried, it was examined under long wave light $(366 \mathrm{~nm})$. The concentration and chemical identity of $\mathrm{AFM}_{1}$ was determined according to Scott (20). Recovery tests were performed to determine the efficacy of the analytical method by spiking aflatoxin raw milk samples with known amounts of $\mathrm{AFM}_{1}(0.01,0.02,0.03,0.05,0.3,0.5 \mu \mathrm{g} / \mathrm{L})$ and submitting them to free extraction procedures in 5 replicates. $\mathrm{AFM}_{1}$ standard was purchased from Sigma Chemical Co (St Louis, MO, USA).

HPLC was performed on GBC system (GBC, Dandenong, Victoria, Australia) equipped with a LC 1110 HPLC pump, a fluorescence detector (model LC 1255) at wavelengths of 360 and $430 \mathrm{~nm}$ for excitation and emission, respectively. The LC column was a LiChrosorb $C_{18}(250 \times 4 \mathrm{~nm}, 10 \mu \mathrm{m}$ - Merck, Darmstadt, Germany). The mobile phase consisted of acetic acid 2\% aqueous solution-acetonitrile-methanol (40:35:25;v/v) and the flow rate was $1 \mathrm{~mL} / \mathrm{min}$. (13). Linearity was determined to be in the range 0.01-0.5 $\mu \mathrm{g} / \mathrm{L}$ of $\mathrm{AFM}_{1}$. Recovery test were performed by spiking aflatoxin-free raw milk samples with known amounts of $\mathrm{AFM}_{1}(0.01,0.02$, and $0.05 \mu \mathrm{g} / \mathrm{L})$.

Some samples analyzed by IC/TLC were submitted to HPLC determination in order to investigate the relationship between the two analytical methods and evaluated the efficiency of TLC in determining $\mathrm{AFM}_{1}$ at low levels. The statistical analysis applied to compare these methods (TLC and HPLC) was based on the " $t$ " Student's test for paired samples, utilizing the Bioestat 3.0 software program.

\section{RESULTS AND DISCUSSION}

\section{Recoveries of $\mathrm{AFM}_{1}$ by TLC and HPLC}

Based on spiked samples, values of recoveries by TLC were $85.8,85.2,85.8,80.8,80.0,73.9 \%$ and the relative standard deviation (RSD) were 7.7, 6.9, 6.0, 6.0, 4.4 and $2.1 \%$ to levels $0.01,0.02,0.03,0.05,0.3$ and $0.5 \mu \mathrm{g} / \mathrm{L}$ respectively. The quantification limit established was $0.02 \mu \mathrm{g} / \mathrm{L}$ and the detection limit was $0.01 \mu \mathrm{g} / \mathrm{L}$. Quantitative TLC requires skilled visual interpretation so divergent visual acuity was taken into consideration in establishing the detection limit in this study.

For HPLC, the calibration curves obtained by least-squares linear regression were linear, in the range $0.010-0.5 \mu \mathrm{g} / \mathrm{L}$, with correlation coefficient of 0.99987 . The recoveries were 86.1, 83.7 and $84.5 \%$ in levels of $0.01,0.02,0.05 \mu \mathrm{g} / \mathrm{L}$. The quantification limit was $0.01 \mu \mathrm{g} / \mathrm{L}$.

The statistical analysis applied to compare these methods (TLC and HPLC) calculating a $\mathrm{p}=0.6059\left(\mathrm{t}_{\text {calculated }}=-0.5345\right.$, $\mathrm{t}_{\text {table }}=2.2622$ and $\alpha=0.05$ ) found no significative difference between the two methods compared (Table 1).

Table 1. Comparison between TLC and HPLC results for $\mathrm{AFM}_{1}$ levels in contaminated milk.

\begin{tabular}{ccc}
\hline Samples & TLC $^{*}(\mu \mathrm{g} / \mathrm{L})$ & HPLC $^{* *}(\mu \mathrm{g} / \mathrm{L})$ \\
\hline 1 & 0.012 & 0.014 \\
2 & 0.035 & 0.034 \\
3 & 0.014 & 0.013 \\
4 & 0.030 & 0.031 \\
5 & 0.146 & 0.136 \\
6 & 0.051 & 0.056 \\
7 & 0.234 & 0.231 \\
8 & 0.263 & 0.278 \\
9 & 0.077 & 0.073 \\
10 & 0.085 & 0.092 \\
\hline
\end{tabular}

*TLC - Thin Layer Chromatography;

*HPLC - High Pressure Liquid Chromatography. 
According Trucksess (24), the number of publications on TLC has declined, but this is not necessarily reflect the extent of its worldwide. Apparently, TLC methods are used routinely but information on their use is not published.

The TLC and HPLC methods employed in this study were optimized in-house and have been utilized as routine in our laboratory

\section{Occurrence of $\mathrm{AFM}_{1}$}

The incidence and levels of $\mathrm{AFM}_{1}$ are summarized in Table 2. From 107 samples analyzed, 79 (73.8\%) were contaminated with $\mathrm{AFM}_{1} . \mathrm{AFM}_{1}$ was detected at low levels $(<0.050 \mu \mathrm{g} / \mathrm{L})$ in $72(67.3 \%)$ of the samples, while $7(6.5 \%)$ samples had the highest value of $>0.05 \mu \mathrm{g} / \mathrm{L}$ and none of the samples exceeded the Brazilian legislation $(0.5 \mu \mathrm{g} / \mathrm{L}$ for fluid milk)

In Brazil, Garrido et al. (6) and Prado et al. (16) found a high incidence of $\mathrm{AFM}_{1}$ (79.9\% and $82.0 \%$, respectively) in low concentrations. Both studies were performed by HPLC. In others studies conducted on $\mathrm{AFM}_{1}$ contamination $(2,14,18$, 22,23 ) the authors found low incidence with varied levels.

As Visconti et al. (26) observed in studies conducted in Italy, the poor sensitivity of the results in the first studies performed in Brazil should be attributed to poor sensitivity of the analytical methods used. In this study, the increased extraction efficacy provided by immunoaffinity column resulted in a high sensitivity to TLC determination.

In comparison with recent data reporting the incidence of $\mathrm{AFM}_{1}$ reported by others investigators $(3,4,5,9,10,11,15,17$, $19,25)$ the results of this study are comparable with those presented in other countries, showing high incidence at low levels. According to Galvano et al. (4), in recent years the incidence of $\mathrm{AFM}_{1}$ has been balanced on the one hand by the higher efficiency of analytical methods, and on the other hand by the setting of a stricter regulatory limit for aflatoxins in feed and milk.

According to Velasco et al. (25) and Markaki and Melissari (10) the present study revealed no significant seasonal differences among contaminated samples. In Brazil, pasture is the major source of cattle feed. The highest level of contamination was found in raw milk $(0.26 \mu \mathrm{g} / \mathrm{L})$, collected in winter. However, this originated from a single (farm) producer, and was thus an isolated case.

Based on the milk samples taken from the cities of São Paulo and Marília (SP), Brazil, during 2001-2002, the occurrence of AFM $_{1}$ does not appear to be a serious public health hazard, according to Brazilian legislation. However, aflatoxins are recurrent and their formation in foods and feeds may sometimes be difficult to avoid. For this reason, specific regulations to control $\mathrm{AFB}_{1}$ in feeds and a systematic $\mathrm{AFM}_{1}$ monitoring program performed by accurate and reliable analytical techniques constitutes an important strategy for protecting milk consumers.

\section{ACKNOWLEDGMENTS}

The authors thank Guilherme P. Andrade for the gift of the immunoaffinity column (AFLAPREPM, R-Biopharm Rhône Ltd).

\section{RESUMO}

\section{Determinação da aflatoxina $M_{1}$ em leite por coluna de imunoafinidade, CCD/CLAE}

No período de 2002 e 2003, cento e sete amostras de leite cru, pasteurizado e UHT (ultrahigh treated temperature) comercializadas nas cidades de São Paulo e Marília (SP) foram analisadas para determinar Aflatoxina $\mathrm{M}_{1}\left(\mathrm{AFM}_{1}\right)$. A aflatoxina $\mathrm{M}_{1}$ foi detectada em $79(73,8 \%)$ amostras, variando de $0,02-$ $0,26 \mu \mathrm{g} / \mathrm{L}$. As amostras foram analisadas utilizando coluna de imunoafinidade para limpeza e cromatografia em camada delgada para determinação da $\mathrm{AFM}_{1}$. Para a otimização do método, os parâmetros avaliados foram: recuperação, repetitividade, limite de detecção e limite de quantificação. Baseado em adição de padrão nas amostras, os valores das recuperações variaram de $85,83 \%$ e $73,86 \%$ em níveis de $0,01-0,5 \mu \mathrm{g} / \mathrm{L}$, respectivamente, e o desvio padrão relativo para repetitividade variou de 7,73-2,08\%. O limite de quantificação foi de $0,02 \mu \mathrm{g} / \mathrm{L}$. Os resultados das amostras analisadas por este método tiveram boa correlação quando comparadas com a Cromatografia Líquida de Alta

Table 2. Occurrence of $\mathrm{AFM}_{1}$ in raw, pasteurized and UHT milk samples.

\begin{tabular}{|c|c|c|c|c|c|}
\hline \multirow{2}{*}{ Type of milk } & \multirow{2}{*}{$\mathrm{N}^{\mathrm{o}}$ of samples } & \multirow{2}{*}{ Contamination $\mu \mathrm{g} / \mathrm{L}(\%)$} & \multicolumn{3}{|c|}{ Frequency distribution of samples in $(\mu \mathrm{g} / \mathrm{L})(\%)$} \\
\hline & & & $>\mathrm{LD}^{* *}$ & $0.02-0.05$ & $>0.05$ \\
\hline Raw & 22 & $0.013(59.1)$ & $05(22.8)$ & $06(27.3)$ & $02(9.0)$ \\
\hline Pasteurized & 43 & $0.032(74.4)$ & $19(44.2)$ & $11(25.6)$ & $02(7.2)$ \\
\hline UHT* $^{*}$ & 42 & $0.034(80.9)$ & $11(26.2)$ & $20(47.6)$ & $03(7.1)$ \\
\hline Total & 107 & $0.079(73.8)$ & $35(32.7)$ & $37(34.6)$ & $7(6.5)$ \\
\hline
\end{tabular}

*UHT - Ultra Hight Temperature; **LD - Detection Limit. 
Eficiência. Concluindo, a utilização de coluna de imunoafinidade fornece excelentes resultados na recuperação, sensibilidade e apresenta fácil operacionalidade. Apesar da alta incidência de aflatoxina $\mathrm{M}_{1}$ em amostras em ambas as cidades, o nível de contaminação pode não ser considerado um sério problema de saúde pública, de acordo com a legislação brasileira.

Palavras-chave: leite, aflatoxina $\mathrm{M}_{1}$, cromatografia em camada delgada, coluna de imunoafinidade

\section{REFERENCES}

1. Brasil. Leis, Decretos, etc. Resolução no 274 de 15/10/2002 da ANVISA. Aprova o Regulamento Técnico sobre limites máximos de aflatoxinas no leite, amendoim e milho. Diário Oficial da União, Brasília, DF, Séc. I, 16 de outubro de 2002.

2. Corrêa, B.; Galhardo, M.; Costa, E.O.; Sabino, M. Distribution of molds and aflatoxin in dairy cattle feeds and raw milk. Rev. Microbiol., 28, 279-283, 1997

3. Galvano, F.; Galofaro, V.; De Angelis, A.; Galvano, M.; Bognanno, M.; Galvano, G. Survey of the occurrence of Aflatoxin $\mathrm{M}_{1}$ in Dairy Products Marketed in Italy. J. Food Prot., 61(6), 738-741, 1998.

4. Galvano, F.; Galofaro, V.; Galvano, G. Occurrence and Stability of Aflatoxin $\mathrm{M}_{1}$ in Milk and Milk Products: a Worldwide Review. $J$. Food Prot., 59(10), 1079-1090, 1996.

5. Galvano, F.; Galofaro, V.; Ritieni, A.; Bognanno, M.; De Angelis, A.; Galvano, G. Survey of the occurrence of aflatoxin $\mathrm{M}_{1}$ in dairy products marketed in Italy: second year of observation. Food Addit. Contam., 18(7), 644-646, 2001.

6. Garrido, N.S.; Iha, M.H.; Ortolani, M.R.S.; Fávaro, R.M.D. Occurrence of aflatoxins $\mathrm{M}_{1}$ and $\mathrm{M}_{2}$ in milk commercialized in Ribeirão Preto-SP, Brazil. Food Addit. Contam., 20(1), 70-73, 2003.

7. Grosso, F.; Fremy, J.M.; Bevis, S.; Dragacci, S. Joint IDF-IUPACIAEA(FAO) Interlaboratory validation for determining aflatoxin $\mathrm{M}_{1}$ in milk by using immunoaffinity clean-up before thin-layer chromatography. Food Addit. Contam., 21(4), 348-357, 2004.

8. Henry, S.H.; Whitaker, T.; Rabbani, I.; Bowers, J.; Park, D.; Price, W.; Bosch, F.X.; Pennington, J.; Verger, P.; Yoshizawa, T.; van Egmond, H.; Jonker, M.A.; Coker, R. In: Safety Evaluation of Certain Mycotoxins in Food; WHO Food Additives Series 47; FAO Food and Nutrition Paper 74; WHO: Geneva, 2001; p.1-102.

9. Kim, E.K.; Shon, D.H.; Ryu, D.; Park, J.W.; Hwang, H.J.; Kim, Y.B. Occurrence of aflatoxin $\mathrm{M}_{1}$ in Korean dairy products determined by ELISA and HPLC. Food Addit. Contam., 17(1), 59-64, 2000.

10. Markaki, P.; Melissari, E. Occurrence of aflatoxin $\mathrm{M}_{1}$ in commercial pasteurized milk determined with ELISA and HPLC. Food Addit. Contam., 14(5), 451-456, 1997.
11. Martins, M.L.; Martins, H.M. Aflatoxin $M_{1}$ in raw and ultra high temperature-treated milk commercialized in Portugal. Food Addit. Contam., 17(10), 871-874, 2000.

12. MERCOSUL/GMC, 1994. Res. No. 56/94, http://www.micotoxinas.com.br/ legisla.html, (03/02/2000)

13. Navas, S.A.; Sabino, M.; Rodriguez-Amaya, D.B. Aflatoxin $M_{1}$ and Ochratoxin A in a human milk bank in the city of São Paulo, Brazil. Food Addit. Contam., 22(5), 348-357, 2004.

14. Oliveira, C.A.F.; Germano, P.M.L. Immunochemical assessment of aflatoxin in milk powder consumed by infants in São Paulo, Brazil. Food Addit. Contam., 14(1), 7-10, 1997.

15. Piva, G.; Pietri, A.; Galazzi, L.; Curto, O. Aflatoxin $\mathrm{M}_{1}$ occurrence in dairy products marketed in Italy. Food Addit. Contam., 5,133-139, 1987.

16. Prado, G.; Oliveira, M.S.; Abrantes, F.M.; Santos, L.G.; Soares, C.R.; Veloso, T. Ocorrência de Aflatoxina $\mathrm{M}_{1}$ em Leite Consumido na Cidade de Belo Horizonte - Minas Gerais/Brasil - Agosto/08 à Abril/ 99. Ciênc. Tecnol Aliment., 19(3), 420-423, 1999.

17. Roussi, V.; Govaris, A.; Varagouli, A.; Botsoglou, N.A. Occurrence of aflatoxin $\mathrm{M}_{1}$ in raw and marketed milk commercialized in Greece. Food Addit. Contam., 19(9), 863-868, 2002.

18. Sabino, M.; Purchio, A.; Zorzetto, M.A.P. Variations in the level of aflatoxin in cows milk consumed in the city of São Paulo, Brazil. Food Addit. Contam., 6(3), 321-326.

19. Saitanu, K. Incidence of aflatoxin $\mathrm{M}_{1}$ in Thai milk products. J Food Prot., 60(8), 1010-1012, 1997.

20. Scott, P.M. Natural Toxins. In: Cunnif, P. (ed). Official Methods of Analysis of Association of Official Analytical Chemists. Gaithersburg, Maryland, 1997, 970. 44, 971.22, 986.16.

21. Shundo, L.; Ruvieri, V.; Navas, S.A.; Sabino, M. Otimização da determinação da aflatoxina $\mathbf{M}_{1}$ em leite, utilizando coluna de imunoafinidade e cromatografia em camada delgada. Rev. Inst. Adolfo Lutz, 63(1), 43-45, 2004.

22. Souza, S.V.C.; Vargas, E.A.; Junqueira, R.G. Efficiency of an ELISA kit in the detection and quantification of aflatoxin $\mathrm{M}_{1}$ in milk and investigation of the occurrence in the State of Minas Gerais. Ciênc. Tecnol. Aliment., 19(3), 401-405, 1999.

23. Sylos, C.M.; Rodriguez-Amaya, D.B.; Carvalho, P.R.N. Occurrence of aflatoxin $\mathrm{M}_{1}$ in milk and dairy products commercialized in Campinas, Brazil. Food Addit. Contam., 13(2), 169-172, 1996.

24. Trucksess, M.W. Rapid analysis (thin layer chromatographic and immunochemical methods) for mycotoxins in foods and feeds. In: de Koe, W.J.; Samsom, R.A.; van Egmond, H.P.; Gilbert, J.; Sabino, M. (eds). Ponsen\&Looyen, Wageningen, The Netherlands, 2001, p. $29-40$.

25. Velasco, M.L.R.; Delso, M.M.C.; Escudero, D.O. ELISA and HPLC determination of the occurrence of aflatoxin $\mathrm{M}_{1}$ in raw cow's milk. Food Addit. Contam., 20(3), 276-280, 2003.

26. Visconti, A.; Bottalico, A.; Solfrizzo, M. Aflatoxin $M_{1}$ in milk in southern Italy. Mycotoxin Res., 1, 71-75, 1985. 